\title{
CO-EXPRESSION OF VIMENTIN AND CYTOKERATIN IN BITCH MAMMARY GLAND TUMORS
}

\author{
JOVIĆ S, MAGAŠ V and ALEKSIĆ-KOVAČEVIĆ SANJA \\ Faculty of Veterinary Medicine, Belgrade \\ (Received 17. December 2006)
}

This work presents the results of immunohistochemical studies on the distribution of intermediary filamentous proteins vimentin and cytokeratin in bitch mammary gland tumors, which had been previously classified according to the latest WHO-classification (1999). The overall test specimen included 45 bitches of different breeds and age, which resulted in diagnosing 27 malignant neoplasms, 11 benign neoplasms, and 3 hyperplastic-dysplastic changes, while 4 test specimens were taken from healthy bitches. The commonest malignant neoplasms were: simple adenocarcinoma (13 cases) and complex adenocarcinoma (7). Among the benign neoplasms the ones that dominated were benign mixed tumors (8 cases).

Vimentin was expressed on neoplastic proliferative suprabasal myoepithelial cells of simple adenocarcinomas; on resting, spindleshaped and star-shaped myoepithelial cells of complex adenocarcinomas; on cartilage cells of carcinomas in the mixed tumor and benign mixed tumors; on osteoid cells of osteosarcoma; and on myofibroblasts of simple adenocarcinomas, complex adenocarcinomas, carcinomas in the mixed tumor and benign mixed tumors, and connective tissue fibres of fibrosarcoma. The expression of cytokeratin was noticed on canalicular and alveolar lumen epithelium of simple adenocarcinomas; on epithelial cells of complex adenocarcinomas, carcinomas in the mixed tumor, mutinous carcinomas, fibrosarcoma and of osteosarcoma; on resting and starshaped myoepithelial cells of complex adenocarcinomas and carcinomas in the mixed tumor; as well as on spindle-shaped myoepithelial cells of carcinomas in the mixed tumor. Proliferative suprabasal myoepithelial cells of simple adenocarcinomas showed the co-expression of vimentin and cytokeratin, and so did the resting and spindle-shaped myoepithelial cells of complex tubular adenocarcinomas, whereas in complex solid adenocarcinomas the coexpression was also shown on star-shaped myoepithelial cells. The coexpression of vimentin and cytokeratin was found on resting myoepithelial cells of benign mixed tumors, simple and complex adenomas, and mammary gland hyperplasia; on spindle-shaped myoepithelial cells of benign mixed tumors, complex adenomas and 
myoepithelial solid adenomas; and on star-shaped myoepithelial cells of benign mixed tumors.

Key words: bitch, mammary gland tumors, expression of vimentin, expression of cytokeratin

\section{INTRODUCTION}

Pathomorphological and pathohistological results are the basic in standing diagnosis of mammary gland tumors. In previous immunohistochemical studies it was established that tumors show cellular pleomorphism. Classification of mammary gland neoplasmic processes in bitches was mostly based on standard histopathological methods. Histogenetical type of classification is obstructed by the determination of specific cells in mammary gland tumors, but also in many conflicting hypothesis in explaining the role of myoepithelial cells in producing frequent mixed type tumors (Misdorp et al., 1999; Mullins et al., 2006).

Adding antibodies specific for some intermedial cell filaments is possible in order to determine the presence, absence or co-expression of different mammary gland tumors, and to determine the origin of the neoplastic process, especially when is present in low differentiated cell populations. Intermediary filamentous proteins: vimentin, cytokeratin (CK), desmin, glial fibrillary acidic protein, and actin as a representer of the microfilamentosal protein group are very usable for the detection of different cell types.

As the expression of intermediary filament proteins is cell and tissue specific, they are important for precise tumor diagnostics in humans and animals. The result of immunohistochemical reactions of normal mammary cells is in most cases similar to reactions which give benignant mammary tumors (Vos et al., 1993; Griffy et al., 1993). Vimentin is expressed in cells of mesenchymal phenotype and used to distinguish between sarcoma from other carcinomas, and melanoma from carcinomas. Combining vimentin and cytokeratin antibodies are displayed in carcinosarcoma and synovial sarcomas. Cytokeratin is significantly present in epithelial cells, thus making them different from mesenchymal and lymphoid cells. This protein appears in bone marrow smears, showing the presence of dissemination of malignant epithelial cells (Korsching et al., 2005). Destructive malignant cell release partially fragmented CK in the blood stream. This can be detected with most of the available comercial kits (Nap et al., 2001). Co-expresion of vimentins and CK in tumors cells is in correlation with the high metastatic potential of these cells (Anguelov, 2000).

Mammary tumors in bitches are the ideal model for studyng the tumors in humans, as they are most similar to the respective tumors in women (they appear in the same stage of life, they are morphologically very common and have the same metastatic potential and prognosis). 
Acta Veterinaria (Beograd), Vol. 57, No. 2-3, 247-255, 2007.

Jović $\mathrm{S}$ et al.: Co-expression of vimentin and cytokeratin

\section{MATERIAL AND METHODS}

\section{Material}

Histological and immunohistochemical researches were done on tissue samples of clinically diagnosed neoplasms in bitch mammary glands, in a variety of ages and breeds. Samples originated from 45 bitches (39 samples were taken after surgical intervention and 2 of them were taken form eutanased bitches). Mammary glands from 4 of clinically healthy bitches served as control samples. All the samples were taken from 3.5-19 year old bitches. 13 specimens belonged to mongrels; 9 German Shepherds; 3 Dachshunds, 3 English Cocker Spaniels, 2 Franch Poodles, 2 Deutscher Jagdterriers and 9 others (1 case from each of the following breeds: Maltese, Doberman Pinscher, American Staffordshire Terrier, Epagneul Breton, Pekingese, English Setter, Boxer Deutcher, Caniche Poodle and Airdale Terrier).

\section{Methods}

Mammary gland tissue samples were fixed in $10 \%$ buffered formalin for about $48 \mathrm{~h}$. After that, they were processed automatically, and the paraffine cuttings (thin 3-5 $\mu \mathrm{m}$ ) were stained with Hematoxilin-eozin, by Weigert Van Gieson method and by peroxidase-anti-peroxidase (PAP). The samples were deparaffined in xylol and rehydrated in a alcohol series. Endogenous peroxidase was blocked with $0.3 \% \mathrm{H}_{2} \mathrm{O}_{2}$ in methanol for 30 min. Protease $(50 \mathrm{mg} / 100 \mathrm{~mL}$ $\mathrm{NaCl} \mathrm{pH}$ 7.8) was used for demasking the antigenic epitops. Preincubation was done in normal $10 \%$ rat serum in TBS. The tissue sections were exposed to primary antibodies on $4^{\circ} \mathrm{C}$ for $12-16 \mathrm{~h}$. After addition of secondary and tertiary antibodies they interacted and were incubated for $30 \mathrm{~min}$. Washing with TBS was carried out between each step of incubation. In the reaction were used: mouse monoclonal anti-vimentin antibodies, 1:50 (Dako No. M 7020); mouse monoclonal anti-cytokeratin antibodies, 1:20 (Boehringer, No 1017 390) and control mouse monoclone antibodies; secondary rat anti mouse, 1:100 (Dako) and PAP mouse 1:500 (Dako). Visuelization was achieved with $0.05 \% 3,3$ diaminobenzidintetrachloridine (DAB) - and counterstained with hematoksilin. A brown colored precipitate confirmed the positive reactions.

Histological classification was determined by WHO-classification of mammary gland tumor in bitches (Misdorp et al., 1999). Analysis of stained histological samples and digital photo documentation were done on a OLYMPUS BX 41 microscope.

\section{RESULTS}

In this paper mammary gland tumors in bitches were classified by WHO classification (Misdorp et al., 1999). According to this criteria a total of $65.85 \%$ (27) malignant neoplasms; 26.82\% (11) benign neoplasms and $7.31 \%$ (3) hyperplastic-dysplastic changes were determined. The most frequent tumor in the studied material was adenocarcinoma (13 cases - 31.70\%). Benign mixed tumors were expressed in 8 cases (19.51\%), complex adenocarcinomas in 7 
cases (17.07\%), malignant mixed tumors (carcinomas in mixed tumors) in 4 cases $(9.75 \%)$. The rest were 3 adenomas $(7.31 \%), 1$ mucinous adenocarcinoma (2.43\%), one fibrosarcoma (2.43\%) and one osteosarcoma (2.43\%). In 3 cases we noticed hyperplastic-dysplastic changes (1 mammary gland hyperplasia - $2.43 \%$, one focal fibrosis $-2.43 \%$ and one chronic steatites - $2.43 \%$ ). The most frequent malignant neoplasms were: adenocarcinoma (48.14\%), complex adenocarcinoma (25.92\%) and carcinoma in the mixed tumors (14.81\%). Most present benign neoplasms were benign mixed tumors (57.14\%) and adenomas (21.42\%).

The majority $(71.05 \%)$ of bitches were pure breed dogs and $28.94 \%$ were half breed dogs. In the reproductive status point of view, the majority of cases were females with no litters (56.09\%) and bitches with only one puppy $(26.82 \%)$. For the first time mammary tumors were detected in $73.17 \%$ of examined biches, and tumor recidives were detected in $14.63 \%$ of them.

In benign mixed tumors expression of vimentin was detected in: resting myoepithelial cells, spindle-shaped myoepithelial cells, star-shaped myoepithelial cells and on cartilage cells. Co-expression of vimentin and cytokeratin was shown in the resting, spindle-shaped and star-shaped myoepithelial cells. In all adenoma samples vimentin was expressed in resting myoepithelial cells and myofibroblasts, but co-expresion of vimentin and cytokeratin was found on resting myoepithelial cells. In complex adenomas, co-expression was determined in resting myoepithelial cells and spindle-shaped myoepithelial cells. In myoepithelial solid adenomas co-expression of vimentin and cytokeratins was shown in spindle-shaped myoepithelial cells. Fibroadenomas resting myoepithelial cell co-expressed both vimentin and cytokeratin.
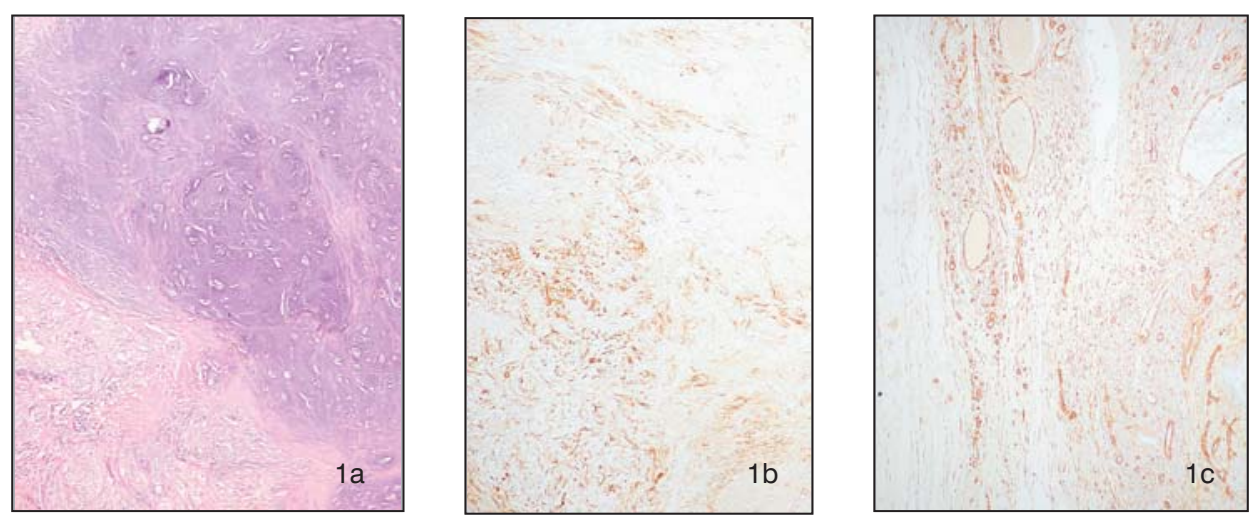

Figure 1. Benign mixed tumors: a) HE, x 100; b) PAP, anti-vimentin, x 200; c) PAP, anticitokeratin, $\times 200$

The expression of vimentin in hyperplasic changes was determined in resting myoepithelial cells and fibroblasts, while the co-expresion of vimentin and 
Acta Veterinaria (Beograd), Vol. 57, No. 2-3, 247-255, 2007.

cytokeratin was shown in resting myoepithelial cells of mammary glands with developed hyperplasia.

Vimentin was expressed in neoplastic proliferated suprabasal myoepithelial cells and myofibroblasts of simple carcinoma. In simple papillary and solid carcinomas, co-expression was manifested in proliferated suprabasal myoepithelial cells. In complex adenocarcinomas vimentin was expressed in resting, spindle-shaped and star-shaped myoepithelial cells, and was especially intensive in myofibroblasts. The resting myoepithelial cells and spindle-shaped myoepithelial cells were co-expresed in complex tubular carcinomas. The resting myoepithelial cells, spindle-shaped myoepithelial cells and star-shaped myoepithelial cells in complex solid carcinomas showed co-expresion of vimentin and cytokeratin.
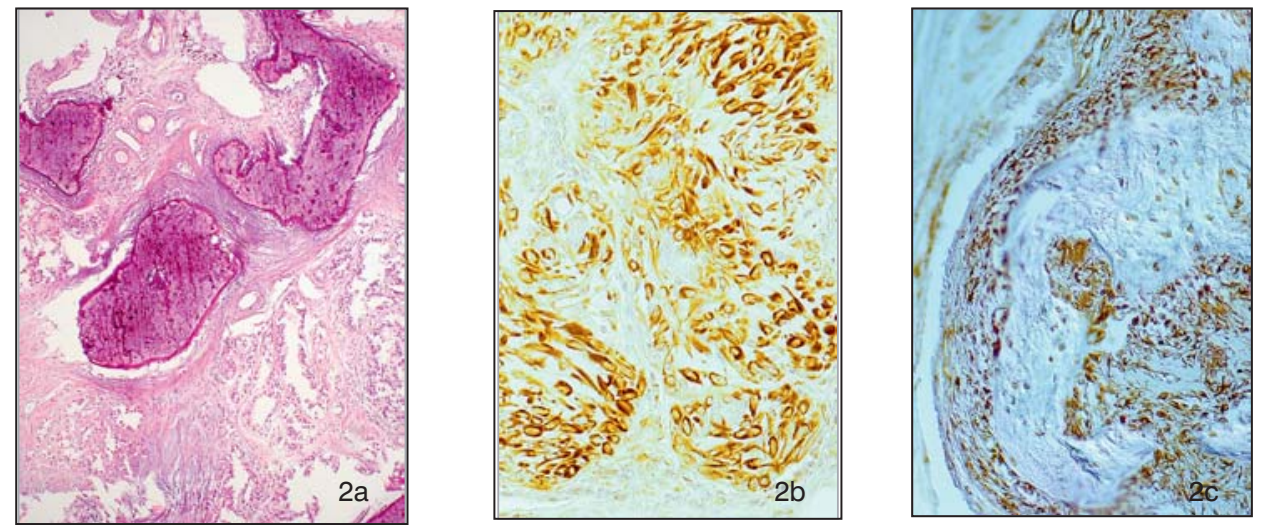

Figure 2. Carcinomas in the mixed tumors: (malignant mixed tumors): a) HE, x 100; b) PAP, anti-vimentin, x 400; c) PAP, anti-citokeratin, x 200

Immunohistochemical vimentin expression in mixed malignant tumors of the mammary gland was proved in cartilage cells and myofibroblast. In one case the expression of vimentin in fibroblasts and connective tissue fibers of fibrosarcoma was diagnostified. The fibrosarcomas neoplastic cells did not coexpress the studied intermediary filamentous proteins. In one case of osteosarcoma a positive immunohistochemical reaction of vimentin was expressed on bone tissue cells and myofibroblasts, but their co-expresion was not found.

\section{DISCUSSION}

Immunohistochemical researches have the decisive role in the precise diagnosis of mammary gland tumors, this is reflected in the use of defined 
therapeutic protocols with a varied survival rate (Gould et al., 1990; Vos et al., 1993). The aim of our research was to bring to light the patohistological analysis and classification of 41 different tumors of the mammary gland based on WHOclassification (Misdorp et al., 1999). According to this criteria we found $65.85 \%$ malignant tumors; $26.82 \%$ benign tumors and $7.31 \%$ hyperplastic-dysplastic changes. Some reports describe the incidence of benign tumors located on mammary gland to be from 9\% to 65\% (Rabanal and Else, 1994; Espinosa de los Monteros et al., 2002). The most common tumors in the studied material were: the simple adenocarcinoma ( 13 cases - $31.70 \%$ ) and benign mixed tumors ( 8 cases $19.51 \%$ ). The results obtained by other authors (Kaldrymidou et al., 1990; Rabanal and Else, 1994; Espinosa de los Monteros et al., 2002) reveal to be most common: carcinomas, carcinomas in mixed tumors, benign mixed tumors and adenomas.

In our study, the average age of studied bitches with confermed mammary gland tumors was 10 years. Other researchers suggest that the development of a tumor is most frequent after 6 years of life and in bitches younger than 2 years (Martin de las Mulas et al., 2002). In our samples pure breed dogs were most common (71.05\%).

With the aim to determine the precise diagnosis and prognosis, mammary gland biopsy samples were used. The level of vimentin and cytokeratin expression depends on tissue type and differentiation. In tissue samples of normal mammary gland cytokeratin was expressed on the canalicular and alveolar luminal epithelium, but vimentin alone was determined only on resting myoepithelial cells (Korsching et al., 2005). Normal mesenchymal tissues and stromal elements of epithelial tissues are positive on vimentin.

Benign mixed tumors (BMT), adenomas and hyperplastic-dysplastic changes, expressed vimentin on resting myoepithelial cells and fibroblasts in hyperplastic-dysplastic changes, myofibroblasts in adenomas. Positive to vimentin were spindle-shaped myoepithelial cells, star-shaped myoepithelial cells and cartilage tissue BMT. This finding is similar with the findings of Helman and Lindgren (1989). Characteristics of mixed mammary gland tumors in bitches are: presence of morphologically different cell types such as cartilage cells, bone cells, fat cells, attached to proliferated luminal epithelial cells (Gartner et al., 1999). Always positive on vimentin are: stromal mesenchymal tissues, including precartilage tissue in complexive tumors and clear differented myoepithelial cells this is the case with the mixed tumor carcinomas (Destexhe et al., 1993; Rabanal and Else, 1994). As vimentin is present typically in the myoepithelial phenotype, his appearance in human carcinomas points to the direct transition of epithelium to mesenchyme, without myoepithelial intervention.

The expression of cytokeratin was noticed on: canalicular and alveolar epithelium of simple adenocarcinomas, epithelial cells of complex adenocarcinomas, carcinomas in mixed tumors, mutinous adenocarcinomas, fibrosarcoma and osteosarcoma, resting and star-shaped myoepithelial cells of complex adenocarcinomas and carcinomas in mixed tumors; as well as on spindle-shaped myoepithelial cells of carcinomas in mixed tumors. Proliferative suprabasal myoepithelial cells of simple adenocarcinomas showed coexpression, and so did resting and spindle-shaped myoepithelial cells of complex 
tubular adenocarcinomas, whereas in complex solid adenocarcinomas the coexpression was also shown on star-shaped myoepithelial cells. The coexpression of intermediary filamentous proteins is characteristic of embryonal tissues, and suggests the inclining to metastases and phenotype cell modifications. The vimentin and cytokeratin co-expression in tumor cells is in correlation with the high metastatic potential of these cells (Schaafsma and Ramaekers, 1994; Anguelov, 2000).

Address for correspondence

Slavoljub Jović

Faculty of Veterinary Medicine

Department of Physiology and Biochemistry

Bul oslobođenja 18, 11000 Beograd

Serbia

e-mail: romanov@vet.bg. ac. yu

\section{REFRENCES}

1. Anguelov Z, 2000, Cytoskeleton Proteins as Markers for an Enhanced Metastatic Potential, New Possibilities in Cancer Management, Currents: Summer 2000, 1, 3

2. Destexhe E, Lespagnard L, Degeyter M, Heymann R, Coignoul F, 1993, Immunohistochemical identification of myoepithelial, epithelial and connective tissue cells in canine mammary tumors, Vet Pathol, 30, 146-54.

3. Espinosa de los Monteros A, Millan MY, Ordas J, Carrasco L, Reymundo C, Martin de las Mulas J, 2002, Immunolocalization of the Smooth Muscle-Specific Protein Calponin in Complex Mixed Tumors of the Mammary Gland of the Dog: Assessment of the Morphogenetic Role of the Myoepithelium, Vet Pathol, 39, 247-56.

4. Gartner F, Geraldes M, Cassali G, Rema A, Schmitt F, 1999, DNA measurement and immunohistochemical characterisation of epithelial and mesenchymal cells in canine mixed tumors: putative evidence for a common histogenesis, Vet $J$, 158, 39-47.

5. Gould VE, Koukoulis GK, Jansson DS, Nagle RB, Franke WW, Moll R, 1990, Coexpression patterns of vimentin and glial filament protein with cytokeratins in the normal, hyperplastics and neoplastic breast, Am J Pathol, 137, 1143-55.

6. Griffy SM, Madewell BR, Dairkee SH, Hunt JE, Naydan DK, Higgins RJ, 1993, Immunohistochemical reactivity of basal and luminal epithelium-specific cytokeratin antibodes within normal and neoplastic canine mammary glands, Vet Pathol, 30, 155-61.

7. Hellmen E, Lindgren A, 1989, The expression of intermediate filaments in canine mammary glands and their tumors, Vet Pathol, 26, 5, 420-8.

8. Kaldrymidou E, Lekkas S, Tsangaris T, Vlemmas I, Karayannopoulou M, 1990, Neoplasms and dysplasia of the canine mammary gland, Bull Hellenic Vet Med Soc, 41, 4, 238-59.

9. Korsching E, Packeisen J, Liedtke C, Hungermann D, Wulfing P, Diest van PJ et al., $H, 2005$, The origin of vimentin expression in invasive breast cancer: epithelial-mesenchymal transition, myoepithelial histogenesis from progenitor cells with bilinear differentiation potential? J Pathol, 206, 4, 451-7.

10. Martin de las Mulas J, Ordas J, Millan MY, Espinosa de los Monteros A, Reymundo C, 2002, Spontaneous Basaloid Adenomas of the Mammary Gland in Four Dogs: Clinicopathologic and Immunohistochemical Features, Vet Pathol, 39, 739-43.

11. Misdorp W, Else RW, Hellmen E, Lipscomb TP, 1999, Histological Classification of mammary tumours of the dog and the cat. WHO international histological classification of tumors of domestic animals, second series volume VII. Published by the Armed Forces Institute of Pathology in cooperation with the American Registry of Pathology and the WHO Collaboration Center for Worldwide Reference on Comparative Oncology, Washington, DC. 
12. Mullins MN, Dernell WS, Withrow SJ, Ehrhart EJ, Thamm DH, Lana SE, 2006, Evaluation of prognostic factors associated with outcome in dogs with multiple cutaneous mast cell tumors treated with surgery with and without adjuvant treatment: 54 cases (1998-2004), J Am Vet Med Assoc, 228, 1, 91-5.

13. Nap M, Wel van Th., Andres C, Bellanger L, Bodenmuller H, Bonfrer H, Brundell J, Einarsson A et al., , 2001, Immunohistochemical Profiles of 30 Monoclonal Antibodies against Cytokeratins 8, 18 and 19, Tumor Biol, 22, 4-10.

14. Rabanal RM, Else RW, 1994, Immunohistochemical localisation of cytokeratin and vimentin intermediate filament proteins in canine mammary tumour, Res Vet Sci, 56, 2, 225-33.

15. Schaafsma HE, Ramaekers FC, 1994, Cytokeratin subtyping in normal and neoplastic epithelium: Basic principles and diagnostic applications, Pathol Ann, 29, 21-62.

16. Vos JH, van den Ingh TSGAM, Misdorp W, Molenbeek RF, van Mil FN, Rutteman GR et al., 1993, Immunohistochemistry with keratin, vimentin, desmin and $\alpha$-smooth muscle actin monoclonal antibodies in canine mammary gland: normal mammary tissue, Vet $Q, 15,3,102-7$.

17. Vos JH, van den Ingh TSGAM, Misdorp W, Molenbeek RF, van Mil FN, Rutteman GR et al, 1993 Immunohistochemistry with keratin, vimentin, desmin and $\alpha$-smooth muscle actin monoclonal antibodies in canine mammary gland: benign mammary tumours and duct ectasias, Vet $Q, 15$, 3, 89-95.

\title{
KOEKSPRESIJA VIMENTINA I CITOKERATINA U TUMORIMA MLEČNE ŽLEZDE KUJA
}

\author{
JOVIĆ S, MAGAŠ V i ALEKSIĆ-KOVAČEVIĆ SANJA
}

\section{SADRŽAJ}

U ovom radu su prikazani rezultati imunohistohemijskog ispitivanja distribucije intermedijernih filamentoznih proteina vimentina i citokeratina u tumorima mlečne žlezde kuja, koji su klasifikovani prema najnovijoj WHO-klasifikaciji iz 1999. godine. Ispitivani uzorak obuhvatio je 45 kuja različite rase i starosti, pri čemu je dijagnostikovano 27 malignih tumora, 11 benignih tumora i 3 benigne promene, dok su 4 kontrolna uzorka bila poreklom od zdravih kuja. Najzastupljeniji maligni tumori bili su prost adenokarcinom (13 slučajeva) i kompleksni adenokarcinom (7 slučajeva), a među benignim tumorima dominirali su benigni mešoviti tumori (8 slučajeva).

Vimentin je bio eksprimiran na neoplastičnim proliferisanim suprabazalnim mioepitelnim ćelijama prostih adenokarcinoma, zatim mirujućim, vretenastim i zvezdastim mioepitelnim ćelijama kompleksnih adenokarcinoma, na hrskavičnim ćelijama benignih i malignih mešovitih tumora, a na osteoblastima osteosarkoma, miofibroblastima prostih adenokarcinoma, kompleksnih adenokarcinoma, malignih i benignih mešovitih tumora, i vezivno-tkivnim vlaknima fibrosarkoma. Ekspresija citokeratina uočena je na alveolarnom i duktalnom epitelu prostih adenokarcinoma, epitelnim ćelijama kompleksnih adenokarcinoma, malignih i benignih mešovitih tumora, mucinoznih adenokarcinoma, fibrosarkoma i osteosarkoma, mirujućim i zvezdastim mioepitelnim ćelijama kompleksnih adenokarcinoma i ma- 
Acta Veterinaria (Beograd), Vol. 57, No. 2-3, 247-255, 2007.

Jović $\mathrm{S}$ et al.: Co-expression of vimentin and cytokeratin

in bitch mammary gland tumors

lignih mešovitih tumora i vretenastim mioepitelnim ćelijama malignih mešovitih tumora. Koekspresiju vimentina i citokeratina pokazuju proliferisane suprabazalne mioepitelne ćelije prostih adenokarcinoma, mirujuće i vretenaste mioepitelne ćelije kompleksnih tubularnih adenokarcinoma, dok je u kompleksnim solidnim adenokarcinoma koekspresija ispoljena i na zvezdastim mioepitelnim ćelijama. Koekspresija vimentina i citokeratina otkrivena je na mirujućim mioepitelnim ćelijama benignih mešovitih tumora, prostih i kompleksnih adenoma i žlezdane hiperplazije; vretenastim mioepitelnim ćelijama benignih mešovitih tumora, kompleksnih adenoma i mioepitelnih solidnih adenoma; i zvezdastim mioepitelnim ćelijama benignih mešovitih tumora. 